\title{
Development and storage study of apricot nectar
}

\author{
Alif Khan ${ }^{1}$, Altaf Ur Rehman ${ }^{1}$, Asad Ali ${ }^{1}$, Hassan Waqas ${ }^{1}$, Zaka Ur \\ Rehman $^{1}$, Shah Saoud ${ }^{1}$, Kashif Akbar ${ }^{1}$ and Ziaur Rahman ${ }^{2 *}$ \\ 1. Department of Food Science \& Technology, The University of Agriculture, Peshawar-Pakistan \\ 2. Department of Agriculture, The University of Swabi, Swabi-Pakistan \\ *Corresponding author's email: zia@uoswabi.edu.pk \\ Citation \\ Alif Khan, Altaf Ur Rehman, Asad Ali, Hassan Waqas, Zaka Ur Rehman, Shah Saoud, Kashif Akbar and Ziaur \\ Rahman. Development and storage study of apricot nectar. Pure and Applied Biology. Vol. 7, Issue 2, pp610-619. \\ http://dx.doi.org/10.19045/bspab.2018.70076
}

Received: 03/02/2018

Revised: 02/05/2018

Accepted: 05/05/2018

Online First: 12/05/2018

\section{Abstract}

This research was performed to check the influence of chemical preservatives such as (potassium metabisulphite, sodium benzoate and potassium sorbate) alone and in grouping to obtain for the overall quality of apricot nectar, the nectar was filled in ( $250 \mathrm{ml}$ plastic bottles) and kept at room temperature for three months. The treatments used in this research were $\mathrm{T} 0=$ Apricot nectar with no preservatives $\mathrm{T} 1=$ Apricot nectar+Potassium metabisulphite $(0.1 \%), \mathrm{T}_{2}=$ Apricot nectar + Sodium benzoate $(0.1 \%), \mathrm{T} 3=$ Apricot nectar + Potassium sorbate $(0.1 \%)$, T 4 =Apricot nectar + Potassium Metabisulphite $(0.05 \%)+$ Sodium benzoate $(0.5 \%)$, T $5=$ Apricot nectar + Potassium Metabisulphite $(0.05 \%)+$ potassium sorbate $(0.05 \%)$, T $6=$ Apricot nectar + sodium benzoate $(0.05 \%)+$ potassium sorbate $(0.05 \%), \mathrm{T} 7=$ Apricot nectar + sodium benzoate $(0.033$ $\%)+$ potassium sorbate $(0.033 \%)+$ Potassium Metabisulphite $(0.033 \%)$. The samples were examined physico-hemically for factors such as, as vitamin $\mathrm{C}, \mathrm{pH}, \mathrm{TSS}$, percent acidity, reducing sugar, non-reducing sugar and organolyptically for color, flavor and overall acceptability. Ascorbic acid decreased from 9.94 to $7.82 \mathrm{mg}$ per $100 \mathrm{~g}$, $\mathrm{pH}$ decreased from 03.89 to 3.23 , TSS increased from 12.05 to 15 brix, acidity grew from 0.29 to $0.42 \%$, reducing sugar rised from 8.12 to $8.59 \%$, non -reducing declined from 4.91 to $4.35 \%$, while the organoleptic values decreased in favor of color declined from 8.06 to 4.97, flavor decreased from 7.96 to5.03 and the values of overall acceptability declined from 8.06 to 4.97. During the study T $6=$ Apricot nectar + sodium benzoate $(0.05 \%)+$ potassium sorbate $(0.05 \%)$ was found most acceptable product followed by $\mathrm{T}$ $3=$ Apricot nectar + Potassium sorbate $0.1 \%$.

Keywords: Acidity; Apricot nectar; Potassium metabisulphite; Reducing sugar; Sodium benzoate; Potassium sorbate; TSS

\section{Introduction}

Apricot (Prunus armeniaca), belongs to the family Rosaceae, is a natural fruit having a stone group in fruit. The consumable part of apricot is mesocarp. It encompass of endocarp while the skin is formed the exocarp is a natural product. The genuine seed is discovered encased inside of the endocarp. The organic product is almost smooth and is of yellow or orange shading. The organic product is eaten crude and in addition in dried and canned structure. World yearly generation of apricot is estimated to 579,000 tones. The fruit Apricot is 
developed in all places all over the world even in Turkey, Iran are world leading producers of apricot, representing a world generation of $20 \%$ and $10 \%$. The fourth largest producer of apricot in the world is Pakistan with an annual production of $1,29,652$ over a region of 13,758 hectares. In Pakistan its life span is very short during usability. Indeed, even cool stockpiling can extend it much. In Pakistan apricot mash is used for assembling distinctive quality included products [1].The apricot has been utilized as a part of society pharmaceutical as a solution for different medicines. An extract of the bark of plant is powerful to calm bothered skin. Different utilizations for apricots in people drug incorporate treatment of hemorrhages, barrenness, eye irritation, and fit. The portion oil has is utilized as a part of beauty care products and medical operators (diuretic and expectorator) [2]. Being perishable natural product Apricot have capacity life of (3-5 days) at surrounding temperature, and barely 2-4 weeks at cool stockpiling. The short stockpiling life of apricot is because of brief time period from business aging to the corruption process trademark like senescence [3]. Distinctive quality included items can be made with apricot like solidified apricot, jam, nectar, jam, jelly, juice, expulsion items and so forth. Also, portion is the critical piece of apricot which can be utilized as a part of the generation of various oils, beauty care products, and smell scents [4]. Diverse techniques are utilized to protect apricot mash yet compound conservation is thought to be the least expensive among various strategies and is entirely basic. It is broadly utilized as a part of Pakistan too. Compound additives are utilized to forestall microorganism brought on sustenance decay. Apricot mash is most regularly ruined by Bacterial and contagious assault which can be controlled by substance additives [1]. There exist various strategies to safeguard apricot mash however concoction protection is thought to be the practical among all techniques for conservation and is general in Pakistan. Synthetic additives are utilized to avert nourishment waste because of microbial assault furthermore that additives particularly (SB and PMS) may now and again disapprovingly impact its physico concoction highlights and tangible representation. In organic product refreshments conservation, the sodium salt of the benzoic corrosive is much of the time utilized, as it is more solvent than the free corrosive; be that as it may, the corrosive framed from the salt broke down in arrangement, is in charge of the antimicrobial movement, which is ideal at a $\mathrm{pH}$ esteem going from 2.5 to 4 [5].

\section{Materials and methods}

This experiment was evaluated at Food Processing and Quality control Laboratory of Pakistan Council of Scientific \& Indus trial Research (PCSIR), Peshawar, KPK Pakistan. Fully ripe and diseased free fruits were selected. The fruits were washed and undesirable portion was removed. Apricot was destoned manually and nectar was extracted by using mechanical nectarier. Through muslin cloth the nectar was extracted in order to remove the unwanted suspended solids and clear the nectar. For making clear Apricot nectar I utilized water, sugar and nectar of apricot in a proper ratio.

\section{Storage study}

These were analyzed ogranolyptically by utilizing 09 points hedonicscale of Larmond [6] for making the most acceptable nectar of apricot fruits. It was then preserved with dissimilar concentration of sodium benzoate, potassium metabisulphate, and potassium sorbate. The sample of apricot nectar was kept in $250 \mathrm{ml}$ pet bottles. Before storage it was first labeled and then stored at ambient temperature for three months and examined for physiochemical and sensory evaluation at 15 days interval. Following 
was various research samples of the best of apricot nectar preserved with different doses of chemical preservatives of potassium metabisulphite sodium benzoate and potassium sorbate.

$\mathrm{T}_{0}=$ Control

$\mathrm{T}_{1}=$ Apricot nectar + Potassium Meta bisulphite $0.1 \%$

$\mathrm{T}_{2}=$ Apricot nectar + Sodium benzoate $0.1 \%$

$\mathrm{T}_{3}=$ Apricot nectar + Potassium sorbate $0.1 \%$

$\mathrm{T}_{4}=$ Apricot nectar + Potassium Meta bisulphite+ Sodium benzoate $0.1 \%$

$\mathrm{T}_{5}=$ Apricot nectar + Potassium Meta bisulphite + potassium sorbate $0.1 \%$

$\mathrm{T}_{6}=$ Apricot nectar + Sodium benzoate +potassium sorbate $0.1 \%$

$\mathrm{T}_{7}=$ Apricot nectar + Sodium benzoate +potassium sorbate+ Potassium Meta bisulphite $0.1 \%$

\section{Physiochemical analysis}

TSS, pH, Acidity, ascorbic acid content, reducing and non-reducing sugars were determined using recommended method of AOAC [7].

\section{Organolyptic evaluation}

Selected samples of apricot nectar were evaluated organolaptically for color, flavor, and overall acceptability by the panels of 10 judges. The evaluation was carried out by using 9 points hedonic scale of Larmond [6].

\section{Statistical analysis}

The data was analyzed statistically by using (CRD) Two Factorial by and means were separated by LSD test at 5\% level of significance as described by Steel and Torrie [8].

\section{Results and discussion}

Physico-chemical properties

pH

The $\mathrm{pH}$ of the samples of apricot treated with chemicals preservatives was initially $\left(\mathrm{T}_{0}\right.$ to $\mathrm{T}_{7}$ ) having values $3.87,3.9,3.89,3.91,3.88$, $3.92,3.92$ and 3.84 which were declined to $3.02,3.18,3.16,3.26,3.15,3.39,3.30$ and
3.21 in that order through storage of 90 days (Table 1). The value of $\mathrm{pH}$ (mean value) significantly $(\mathrm{p}<0.05)$ drop off from 3.64 to 3.40 during storage. Representing treatments largest value for mean were pragmatic in sample $\mathrm{T}_{6}$ (3.64) followed by $\mathrm{T}_{5}$ (3.62), whereas smallest for (mean) was pointed out in $\mathrm{T}_{0}$ (3.40) followed by $\mathrm{T}_{1}$ (3.51). During treatment storage highest decline was noted in $\mathrm{T}_{0}(21.96 \%)$ followed by $\mathrm{T}_{4}(18.8 \%)$ although lowest decrease was pragmatic in $\mathrm{T}_{5}(13.5)$ followed by $\mathrm{T}_{6}(15.81 \%)$.

The $\mathrm{pH}$ value drop down during storage was due to the formation of acidic compounds. The final outcome were related with Lindorth [9], Ehsan et al. [10]. Ehsan et al. [11]. And Shakiret al. [12].

TSS: The TSS of the samples of apricot treated with chemicals preservatives was initially $\left(\mathrm{T}_{0}\right.$ to $\left.\mathrm{T}_{7}\right)$ having values12.1,12,12.1,12,12,12.1,12.1, and 12 which were gradually increased to $15.2,15.4,15.0,14.9,14.8,15.1,14.7$, and 14.9 respectively during storage at ambient temperature for 90 days (Table 2). The (mean) value for TSS was significantly $(p<0.05)$ raised from 13.32 to 13.65 during storage. During experiment the value for mean were inclined in sample $\mathrm{T}_{0}(13.65)$ followed by $T_{1}(13.60)$, at the same time as lowest mean value was noted in $\mathrm{T}_{6}$ (13.32) followed by $\mathrm{T}_{7}$ (13.34). Through analysis highest inclined was initiate in $\mathrm{T}_{1}(28.33 \%$ ) followed by $\mathrm{T}_{0}(25.6 \%)$ while lowest improvement was start in $\mathrm{T}_{6}(21.48 \%)$ followed by $\mathrm{T}_{4}(23.33 \%)$. The rise in TSS during storage is due to the reverse effect of sucrose into the glucose and fructose and also due to the higher temperature. In contrast the ripe fruits contain high sugar content for nectars which might be related with the conversion of starch into soluble sugars by phosphorylase enzyme during the process of ripening Germain \& Linden [13], Favier et al [14]. 
Table 1. pH of apricot nectar stored at room temperature

\begin{tabular}{|c|c|c|c|c|c|c|c|c|c|}
\hline & \multicolumn{7}{|c|}{ Storage Interval (Days) } & \multirow{2}{*}{ Means } & \% Decrease \\
\cline { 2 - 10 } Treatments & $\begin{array}{c}\text { Initial } \\
\text { Reading }\end{array}$ & $\mathbf{1 5}$ & $\mathbf{3 0}$ & $\mathbf{4 5}$ & $\mathbf{6 0}$ & $\mathbf{7 5}$ & $\mathbf{9 0}$ & & \\
\cline { 2 - 10 } & \multicolumn{8}{|c|}{$\mathbf{p H}$} \\
\hline $\mathrm{T}_{0}$ & 3.87 & 3.71 & 3.52 & 3.39 & 3.2 & 3.14 & 3.02 & $3.40 \mathrm{e}$ & 21.96 \\
\hline $\mathrm{T}_{1}$ & 3.89 & 3.77 & 3.63 & 3.54 & 3.32 & 3.29 & 3.16 & $3.51 \mathrm{~d}$ & 18.76 \\
\hline $\mathrm{T}_{2}$ & 3.9 & 3.82 & 3.71 & 3.52 & 3.47 & 3.23 & 3.18 & $3.54 \mathrm{c}$ & 18.46 \\
\hline $\mathrm{T}_{3}$ & 3.91 & 3.84 & 3.75 & 3.6 & 3.48 & 3.33 & 3.26 & $3.59 \mathrm{~b}$ & 16.62 \\
\hline $\mathrm{T}_{4}$ & 3.88 & 3.72 & 3.63 & 3.58 & 3.39 & 3.28 & 3.15 & $3.51 \mathrm{~d}$ & 18.81 \\
\hline $\mathrm{T}_{5}$ & 3.92 & 3.84 & 3.78 & 3.69 & 3.51 & 3.4 & 3.39 & $3.62 \mathrm{~b}$ & 13.5 \\
\hline $\mathrm{T}_{6}$ & 3.92 & 3.85 & 3.76 & 3.64 & 3.59 & 3.48 & 3.3 & $3.64 \mathrm{a}$ & 15.81 \\
\hline $\mathrm{T}_{7}$ & 3.84 & 3.76 & 3.63 & 3.59 & 3.41 & 3.38 & 3.21 & $3.54 \mathrm{c}$ & 16.4 \\
\hline Mean & 3.89 & 3.8 & 3.69 & 3.59 & 3.45 & 3.34 & 3.34 & 3.23 & \\
\hline
\end{tabular}

Figures with different small letters are statistically different $(\mathrm{p}<0.05)$

Table 2. Total soluble solid (TSS) ${ }^{0}$ Brix of Apricot nectar stored at room temperature

\begin{tabular}{|c|c|c|c|c|c|c|c|c|c|}
\hline \multirow{3}{*}{ Treatments } & \multicolumn{7}{|c|}{ Storage Interval (Days) } & \multirow[t]{2}{*}{ Means } & \multirow{2}{*}{$\begin{array}{c}\% \\
\text { increase }\end{array}$} \\
\hline & $\begin{array}{c}\text { Initial } \\
\text { Reading }\end{array}$ & 15 & 30 & 45 & 60 & 75 & 90 & & \\
\hline & \multicolumn{9}{|c|}{ TSS ("brix) } \\
\hline $\mathrm{T}_{0}$ & 12.1 & 12.6 & 13.1 & 13.8 & 14.1 & 14.7 & 15.2 & $13.65 \mathrm{a}$ & 25.6 \\
\hline $\mathrm{T}_{1}$ & 12 & 12.4 & 12.9 & 13.4 & 14.2 & 14.9 & 15.4 & $13.6 \mathrm{~b}$ & 28.33 \\
\hline $\mathrm{T}_{2}$ & 12.1 & 12.6 & 13.1 & 13.7 & 14 & 14.5 & 15 & $13.57 \mathrm{~d}$ & 23.96 \\
\hline $\mathrm{T}_{3}$ & 12 & 12.3 & 12.9 & 13.5 & 13.9 & 14.4 & 14.9 & $13.41 \mathrm{e}$ & 24.16 \\
\hline $\mathrm{T}_{4}$ & 12 & 12.4 & 12.8 & 13.4 & 13.9 & 14.4 & 14.9 & $13.4 \mathrm{f}$ & 24.16 \\
\hline $\mathrm{T}_{5}$ & 12.1 & 12.5 & 13 & 13.6 & 14.1 & 14.7 & 15.1 & $13.58 \mathrm{c}$ & 24.7 \\
\hline $\mathrm{T}_{6}$ & 12.1 & 12.4 & 12.9 & 13.3 & 13.8 & 14.1 & 14.7 & $13.32 \mathrm{~h}$ & 21.48 \\
\hline $\mathrm{T}_{7}$ & 12 & 12.4 & 12.8 & 13.3 & 13.8 & 14.3 & 14.8 & $13.34 \mathrm{~g}$ & 23.33 \\
\hline Mean & $12.05 \mathrm{~g}$ & $12.45 \mathrm{f}$ & $12.93 \mathrm{e}$ & $13.5 \mathrm{~d}$ & $13.97 \mathrm{c}$ & $14.5 \mathrm{~b}$ & $15 \mathrm{a}$ & & \\
\hline
\end{tabular}

Figures with different small letters are statistically different $(\mathrm{p}<0.05)$

\section{Acidity}

The acidity of the samples of apricot treated with chemicals preservatives was initially ( $\mathrm{T}_{0}$ to $\mathrm{T}_{7}$ ) having values $0.32,0.29,0.31$, $0.31,0.27,0.28,0.30$ and 0.28 which were gradually increased to $0.45,0.42,0.43,0.44$, $0.41,0.43,0.43,0.39$ and 0.42 respectively during storage (Table 3 ). TSS value was significantly $(\mathrm{p}<0.05)$ inclined from 0.34 to 0.37 during research. Highest mean value were examined in sample $\mathrm{T}_{0}(0.37)$ followed by $\mathrm{T}_{1}(0.37)$, whereas decline (mean) value was pragmatic in $\mathrm{T}_{6}(0.34)$ followed by $\mathrm{T}_{7}$ (0.34). Maximum enhance was establish in $\mathrm{T}_{5}(53.57 \%)$ followed by $\mathrm{T}_{7}(51.85 \%)$ while lowest was noted in $\mathrm{T}_{6}(30.00 \%)$ followed by
$\mathrm{T}_{4}$ (3 8.7\%). Abbasi et al. [15].examined the percentage acidity inclined and $\mathrm{pH}$ decline during storage with increase in storage time of mangoes.

\section{Ascorbic acid}

The value of ascorbic acid of the samples of apricot treated with chemicals preservatives was initially $\left(\mathrm{T}_{0}\right.$ to $\left.\mathrm{T}_{7}\right)$ having values $9.9,10$, 9.9, 9.9, 10, 9.9, 10 and 9.9 which were gradually decreased to $7.2,8.3,8.0,7.9,7.4$, $7.3,8.1$ and 7.8respectively during storage of (90) days (Table 4). The $\mathrm{pH}$ value for (mean) significantly $(\mathrm{p}<0.05)$ drop from 9.18 to 8.6 during the period of storage. During storage highest value for mean were pointed out in sample $\mathrm{T}_{6}$ (9.18) followed by $\mathrm{T}_{7}(9.05)$, 
whereas lowest was noted in $\mathrm{T}_{0}$ (8.6) followed by $T_{1}(8.65)$. In research highest decrease was initiate in $\mathrm{T}_{0}(27.7)$ followed by $\mathrm{T}_{4}$ ( 26 ) while smallest decline was noted in $\mathrm{T}_{7}(17 \%)$ followed by $\mathrm{T}_{1}$ ( 19 $\%$ ). (The data are in conformity with the findings of Zeb et al. [16]. during storage of grape juice with sodium benzoate and potassium sorbate, stored at room temperature for one month storage period, who observed decrease in ascorbic acid content of grape juice. The results of Ayub et al. [17] are in agreement with our results, who observed decrease in ascorbic acid content of pomegranate syrup, preserved under different light conditions and different packaging materials at room temperature for storage period of four months.)

Table 3. Acidity of Apricot nectar stored at room temperature

\begin{tabular}{|c|c|c|c|c|c|c|c|c|c|}
\hline \multirow{3}{*}{ Treatments } & \multicolumn{7}{|c|}{ Storage Interval (Days) } & \multirow[b]{2}{*}{ Means } & \multirow{2}{*}{$\%$ increase } \\
\hline & $\begin{array}{c}\text { Initial } \\
\text { Reading }\end{array}$ & 15 & 30 & 45 & 60 & 75 & 90 & & \\
\hline & \multicolumn{9}{|c|}{ Acidity (\%) } \\
\hline $\mathrm{T}_{0}$ & 0.32 & 0.33 & 0.35 & 0.38 & 0.39 & 0.43 & 0.45 & $0.37 \mathrm{a}$ & 40.62 \\
\hline $\mathrm{T}_{1}$ & 0.31 & 0.33 & 0.36 & 0.37 & 0.38 & 0.42 & 0.44 & $0.37 \mathrm{~b}$ & 41.95 \\
\hline $\mathrm{T}_{2}$ & 0.29 & 0.31 & 0.33 & 0.36 & 0.38 & 0.4 & 0.42 & $0.35 \mathrm{~d}$ & 45 \\
\hline $\mathrm{T}_{3}$ & 0.28 & 0.3 & 0.33 & 0.35 & 0.38 & 0.39 & 0.42 & $0.35 \mathrm{e}$ & 50 \\
\hline $\mathrm{T}_{4}$ & 0.31 & 0.34 & 0.37 & 0.38 & 0.39 & 0.41 & 0.43 & $0.37 \mathrm{ab}$ & 38.7 \\
\hline $\mathrm{T}_{5}$ & 0.28 & 0.32 & 0.34 & 0.37 & 0.39 & 0.41 & 0.43 & $0.36 \mathrm{c}$ & 53.57 \\
\hline $\mathrm{T}_{6}$ & 0.3 & 0.31 & 0.32 & 0.34 & 0.35 & 0.37 & 0.39 & $0.34 \mathrm{f}$ & 30 \\
\hline $\mathrm{T}_{7}$ & 0.27 & 0.31 & 0.32 & 0.35 & 0.37 & 0.39 & 0.41 & $0.34 \mathrm{e}$ & 51.85 \\
\hline Mean & $0.29 \mathrm{~g}$ & $0.31 \mathrm{f}$ & $0.33 \mathrm{e}$ & $0.36 \mathrm{~d}$ & $0.37 \mathrm{c}$ & $0.39 b$ & $0.42 \mathrm{a}$ & & \\
\hline
\end{tabular}

Figures with different small letters are statistically different $(\mathrm{p}<0.05)$

Table 4. Ascorbic acid (mg/100ml) of Apricot nectar stored at room temperature

\begin{tabular}{|c|c|c|c|c|c|c|c|c|c|}
\hline & \multicolumn{7}{|c|}{ Storage Interval (Days) } & \multirow{2}{*}{ Means } & \multirow{2}{*}{$\begin{array}{c}\text { \% } \\
\text { Decrease }\end{array}$} \\
\cline { 2 - 9 } Treatments & $\begin{array}{c}\text { Initial } \\
\text { Reading }\end{array}$ & $\mathbf{1 5}$ & $\mathbf{3 0}$ & $\mathbf{4 5}$ & $\mathbf{6 0}$ & $\mathbf{7 5}$ & $\mathbf{9 0}$ & & \\
\cline { 2 - 9 } & \multicolumn{8}{|c|}{ Ascorbic Acid (mg/100gm) } \\
\hline $\mathrm{T}_{0}$ & 9.9 & 9.5 & 9 & 8.7 & 8.2 & 7.7 & 7.2 & $8.6 \mathrm{~d}$ & 27.27 \\
\hline $\mathrm{T}_{1}$ & 10 & 9.8 & 9.5 & 9.2 & 8.9 & 8.6 & 8.3 & $9.05 \mathrm{~b}$ & 19 \\
\hline $\mathrm{T}_{2}$ & 9.9 & 9.7 & 9.2 & 8.9 & 8.6 & 8.3 & 8 & $8.94 \mathrm{bc}$ & 19.16 \\
\hline $\mathrm{T}_{3}$ & 9.9 & 9.5 & 9.3 & 8.8 & 8.4 & 8.1 & 7.9 & $8.84 \mathrm{c}$ & 19.19 \\
\hline $\mathrm{T}_{4}$ & 10 & 9.6 & 9.1 & 8.6 & 8.1 & 7.8 & 7.4 & $8.65 \mathrm{~b}$ & 26 \\
\hline $\mathrm{T}_{5}$ & 9.9 & 9.6 & 9.2 & 8.7 & 8.2 & 7.8 & 7.3 & $8.67 \mathrm{be}$ & 20.2 \\
\hline $\mathrm{T}_{6}$ & 10 & 9.8 & 9.4 & 9 & 8.7 & 8.4 & 8.1 & $9.18 \mathrm{a}$ & 17 \\
\hline $\mathrm{T}_{7}$ & 9.9 & 9.6 & 9.3 & 8.9 & 8.6 & 8.1 & 7.8 & $8.88 \mathrm{f}$ & 21.21 \\
\hline Mean & $9.94 \mathrm{a}$ & $9.65 \mathrm{~b}$ & $9.28 \mathrm{c}$ & $8.87 \mathrm{~d}$ & $8.5 \mathrm{e}$ & $8.15 \mathrm{f}$ & $7.82 \mathrm{~g}$ & & \\
\hline
\end{tabular}

Figures with different small letters are statistically different $(\mathrm{p}<0.05)$

\section{Reducing sugar}

The reducing sugar of the samples of apricot treated with chemicals preservatives was initially $\left(\mathrm{T}_{0}\right.$ to $\mathrm{T}_{7}$ ) having values $8.11,8.12$, $8.11,8.12,8.11,8.12,8.11$ and 8.12 which were gradually increased to $8.65,8.67,8.50$, $8.62, \quad 8.66, \quad 8.51, \quad 8.53$ and 8.59 correspondingly during storage (Table 5). The (mean value) for reducing sugar significantly $(\mathrm{p}<0.05)$ enhance from 0.34 to 
0.37 during experiment. In apricot treatments maximum (mean value) were noted in sample $\mathrm{T}_{0}$ (8.42) followed by $\mathrm{T}_{1}$ (8.40), while minimum (mean value) was evaluated in $\mathrm{T}_{6}$ (8.32) followed by $\mathrm{T}_{7}$ (8.37). During storage of apricot highest inclined was noted in $\mathrm{T}_{2}$ (6.78\%) followed by $\mathrm{T}_{7} \quad(6.77 \%)$ although smallest decline was indicated in $\mathrm{T}_{2}(4.80 \%)$ followed by $\mathrm{T}_{5}(4.82 \%)$. The present study are agreement with Ayub et al [17]. Increase in reducing sugars of fruits nectar and juices durijng storage were confirmed by several researchers [18, 19]. Studies of Iqbal [19] also showed that increase in reducing sugars was due to the conversion of sucrose to glucose and fructose and so on.

Table 5. Reducing sugar of Apricot nectar stored at room temperature

\begin{tabular}{|c|c|c|c|c|c|c|c|c|c|}
\hline \multirow{2}{*}{ Treatments } & \multicolumn{7}{|c|}{ Storage Interval (Days) } & \multirow{2}{*}{ Means } & \% increase \\
\cline { 2 - 10 } & $\begin{array}{c}\text { Initial } \\
\text { Reading }\end{array}$ & $\mathbf{1 5}$ & $\mathbf{3 0}$ & $\mathbf{4 5}$ & $\mathbf{6 0}$ & $\mathbf{7 5}$ & $\mathbf{9 0}$ & \\
\cline { 2 - 10 } Reducing Sugar \\
\hline $\mathrm{T}_{0}$ & 8.11 & 8.24 & 8.36 & 8.45 & 8.53 & 8.61 & 8.65 & $8.42 \mathrm{a}$ & 6.65 \\
\hline $\mathrm{T}_{1}$ & 8.11 & 8.22 & 8.34 & 8.43 & 8.51 & 8.59 & 8.66 & $8.40 \mathrm{~b}$ & 6.78 \\
\hline $\mathrm{T}_{2}$ & 8.11 & 8.21 & 8.33 & 8.41 & 8.53 & 8.64 & 8.5 & $8.39 \mathrm{c}$ & 4.8 \\
\hline $\mathrm{T}_{3}$ & 8.12 & 8.21 & 8.32 & 8.4 & 8.49 & 8.56 & 8.62 & $8.38 \mathrm{c}$ & 6.15 \\
\hline $\mathrm{T}_{4}$ & 8.12 & 8.19 & 8.24 & 8.31 & 8.4 & 8.51 & 8.59 & $8.38 \mathrm{f}$ & 5.78 \\
\hline $\mathrm{T}_{5}$ & 8.12 & 8.23 & 8.37 & 8.46 & 8.55 & 8.61 & 8.51 & $8.40 \mathrm{~b}$ & 4.8 \\
\hline $\mathrm{T}_{6}$ & 8.11 & 8.2 & 8.29 & 8.31 & 8.39 & 8.46 & 8.53 & $8.32 \mathrm{e}$ & 5.17 \\
\hline $\mathrm{T}_{7}$ & 8.12 & 8.19 & 8.25 & 8.36 & 8.42 & 8.59 & 8.67 & $8.37 \mathrm{~d}$ & 6.77 \\
\hline $\mathrm{Mean}_{4}$ & $8.11 \mathrm{~g}$ & $8.21 \mathrm{f}$ & $8.31 \mathrm{e}$ & $8.39 \mathrm{~d}$ & $8.47 \mathrm{c}$ & $8.57 \mathrm{~b}$ & $8.59 \mathrm{a}$ & & \\
\hline
\end{tabular}

Figures with different small letters are statistically different $(\mathrm{p}<0.05)$

\section{Non reducing sugar}

The non-reducing sugar of the samples of apricot treated with chemicals preservatives was initially ( $\mathrm{T}_{0}$ to $\mathrm{T}_{7}$ ) having values 4.92 , 4.91, 4.91, 4.92, 4.91, 4.91, 4.92 and 4.91 which were gradually decreased to 4.28 , $4.31,4.37,4.36,4.41,4.35,4.39$ mand 4.38 respectively during storage of apricot nectar (Table 6). The (mean value) for non-reducing sugar significantly $(\mathrm{p}<0.05)$ decreased from 4.65 to 4.63 during storage. During research maximum (mean value) were pointed out in sample $\mathrm{T}_{6}$ (4.65) followed by $\mathrm{T}_{7}$ (4.64), although smallest (mean value) was indicated in $\mathrm{T}_{0}$ (4.63) followed by $\mathrm{T}_{1}$ (4.62). In apricot nectar largest increase was noted in $\mathrm{T}_{1}$ $(14.63 \%)$ followed by $\mathrm{T}_{0}(13.0 \%)$ whereas lowest decline was found in $\mathrm{T}_{6}(10.77 \%)$ followed by $\mathrm{T}_{7}$ (10.79\%).Expanding in decreasing sugars amid capacity time is because of the change of sucrose's into glucoses and fructose's. Same kind examination was additionally done by Baksky et al [20]. Pruithi et al. [21].that nondecreasing sugar is changed over into lessening sugars of beverages amid capacity. Organoleptic evaluation

Samples of apricot nectar were studied for flavor color and overall acceptability by the recommended method larmond [6]. Panel of 10 judges were consigned to score then among 9-1. Principally like and dislike was symbol zed with 9 and 1 respectively. 
Table 6. Non reducing sugar of Apricot nectar stored at room temperature

\begin{tabular}{|c|c|c|c|c|c|c|c|c|c|}
\hline & \multicolumn{7}{|c|}{ Storage Interval (Days) } & \multirow{2}{*}{ Means } & \multicolumn{2}{c|}{$\begin{array}{c}\text { \% } \\
\text { Decrease }\end{array}$} \\
\cline { 2 - 10 } Treatments & $\begin{array}{c}\text { Initial } \\
\text { Reading }\end{array}$ & $\mathbf{1 5}$ & $\mathbf{3 0}$ & $\mathbf{4 5}$ & $\mathbf{6 0}$ & $\mathbf{7 5}$ & $\mathbf{9 0}$ & & \\
\cline { 2 - 10 } & \multicolumn{8}{|c|}{ Non Reducing sugar } \\
\hline $\mathrm{T}_{0}$ & 8.1 & 7.2 & 6.6 & 5.8 & 4.5 & 3.9 & 3.4 & $5.64 \mathrm{f}$ & 58.02 \\
\hline $\mathrm{T}_{1}$ & 7.8 & 7.3 & 6.7 & 6.1 & 5.9 & 5.2 & 4.8 & $6.3 \mathrm{e}$ & 40.74 \\
\hline $\mathrm{T}_{2}$ & 7.9 & 7.5 & 7 & 6.7 & 6.1 & 5.7 & 5.1 & $6.6 \mathrm{bc}$ & 36.25 \\
\hline $\mathrm{T}_{3}$ & 8 & 7.4 & 7 & 6.8 & 6.3 & 5.9 & 5.2 & $6.68 \mathrm{~b}$ & 35 \\
\hline $\mathrm{T}_{4}$ & 7.9 & 7.5 & 7.1 & 6.5 & 5.9 & 5.3 & 4.9 & $6.47 \mathrm{~d}$ & 39.5 \\
\hline $\mathrm{T}_{5}$ & 7.8 & 7.4 & 6.9 & 6.4 & 5.9 & 5.3 & 4.8 & $6.41 \mathrm{~d}$ & 40.74 \\
\hline $\mathrm{T}_{6}$ & 8.1 & 7.4 & 7.1 & 6.9 & 6.5 & 6.1 & 5.8 & $6.84 \mathrm{a}$ & 28.39 \\
\hline $\mathrm{T}_{7}$ & 8 & 7.2 & 6.8 & 6.3 & 6 & 5.8 & 5.4 & $6.5 \mathrm{~cd}$ & 32.5 \\
\hline Mean & $8.06 \mathrm{a}$ & $7.36 \mathrm{~b}$ & $6.9 \mathrm{c}$ & $6.43 \mathrm{~d}$ & $5.88 \mathrm{e}$ & $5.4 \mathrm{f}$ & $4.97 \mathrm{~g}$ & & \\
\hline
\end{tabular}

Figures with different small letters are statistically different $(\mathrm{p}<0.05)$

\section{Color}

The color of the samples of apricot treated with chemicals preservatives was initially ( $\mathrm{T}_{0}$ to $\mathrm{T}_{7}$ ) having values $8.1,7.8,8,0,8.0,7.9$, $7.8,8.1$ and 7.9 which were gradually decreased to $3.4,4.8,5.4,5.2,4.9,4.8,5.8$ and 5.1 correspondingly during storage of 90 days (Table 7). The (mean value) significantly $(\mathrm{p}<0.05)$ drop down from 6.84 to 5.64 during the experiment. In the treatments of apricot nectar maximum (mean value) were indicated in sample $\mathrm{T}_{6}(6$ .84) followed by $T_{7}(6.6)$, although lowest value for (mean) was noted in $\mathrm{T}_{0}$ (5.64) followed by $T_{1}$ (6.30).During research highest decline was pointed out in $\mathrm{T}_{0}$ $(58.02 \%)$ followed by $\mathrm{T}_{1}(40.74 \%)$ while smallest value was indicated in $\mathrm{T}_{7}(28.39 \%)$ followed by $\mathrm{T}_{6}(32.5 \%)$. Color changes due to Millard reaction between amino acids and sugar. Gonzalez et al. [22]. (Color changes in ripening fruit have been correlated by the consumer with the conversion of starch to sugar that is, sweetening and the development of other desirable attributes so that the correct skin color is often all required for a decision to purchase the commodity (Wills et al. [23].

\section{Flavor}

The flavor of the samples of apricot treated with chemicals preservatives was initially ( $\mathrm{T}_{0}$ to $\mathrm{T}_{7}$ ) having values $7.9,7.8,7.9,8.0,7.8$, $7.9,8.0$ and 7.9 which were steadily reduced to $3.1,5.3,5.1,5.5,5.6,5.2,5.4$ and 5.1 correspondingly during storage days (Table 8). During flavor storage of apricot the (mean value) significantly $(\mathrm{p}<0.05)$ decline from 6.65 to 5.62 during storage. In apricot nectar highest (mean value) were identified in sample $\mathrm{T}_{6}$ (6.65) followed by $\mathrm{T}_{7}$ (6.58), whereas smallest (mean value) was pointed out in $\mathrm{T}_{0}$ (5.62) followed by $\mathrm{T}_{1}$ (6.30). During storage highest decline was pointed out in $\mathrm{T}_{0}$ $(53.16 \%)$ followed by $\mathrm{T}_{1}(35.44 \%)$ whereas lowest value was noted in $\mathrm{T}_{7}(30.0 \%)$ followed by $\mathrm{T}_{6}(32.5 \%)$. The results indicated that during storage there was gradual decrease in flavor of drinks. A decrease in flavor score may be attributed to the increase in acidity of drinks. A gradual decrease in flavor during storage may also be due to heat treatment applied during processing as reported by Pruthi et al. [21]. 
Table 7. Color of Apricot nectar stored at room temperature

\begin{tabular}{|c|c|c|c|c|c|c|c|c|c|}
\hline \multirow[b]{2}{*}{ Treatments } & \multicolumn{7}{|c|}{ Storage Interval (Days) } & \multirow{2}{*}{ Means } & \multirow{2}{*}{$\begin{array}{c}\% \\
\text { Decrease }\end{array}$} \\
\hline & $\begin{array}{c}\text { Initial } \\
\text { Reading }\end{array}$ & 15 & 30 & 45 & 60 & 75 & 90 & & \\
\hline & \multicolumn{9}{|c|}{ Score Rate for Color } \\
\hline $\mathrm{T}_{0}$ & 7.9 & 7.3 & 6.8 & 5.9 & 4.6 & 3.8 & 3.1 & $5.62 \mathrm{e}$ & 53.16 \\
\hline $\mathrm{T}_{1}$ & 7.9 & 7.2 & 6.7 & 6.1 & 5.8 & 5.3 & 5.1 & $6.3 \mathrm{~d}$ & 35.44 \\
\hline $\mathrm{T}_{2}$ & 7.8 & 7.4 & 7 & 6.5 & 6.1 & 5.7 & 5.3 & $6.57 \mathrm{ab}$ & 33.75 \\
\hline $\mathrm{T}_{3}$ & 8 & 7.1 & 6.8 & 6.3 & 6 & 5.8 & 5.5 & $6.5 b c$ & 31.25 \\
\hline $\mathrm{T}_{4}$ & 7.9 & 7.5 & 7.1 & 6.6 & 5.9 & 5.5 & 5.1 & $6.52 b c$ & 36.25 \\
\hline $\mathrm{T}_{5}$ & 7.9 & 7.2 & 6.9 & 6.3 & 6 & 5.7 & 5.2 & $6.45 c$ & 34.17 \\
\hline $\mathrm{T}_{6}$ & 8 & 7.5 & 7 & 6.6 & 6.2 & 5.9 & 5.4 & $6.65 \mathrm{a}$ & 32.5 \\
\hline $\mathrm{T}_{7}$ & 7.8 & 7.3 & 6.8 & 6.4 & 6.1 & 5.9 & 5.6 & $6.58 \mathrm{ab}$ & 30 \\
\hline Mean & $7.96 \mathrm{a}$ & $7.31 \mathrm{~b}$ & $6.88 \mathrm{c}$ & $6.33 \mathrm{~d}$ & $5.83 \mathrm{e}$ & $5.4 \mathrm{f}$ & $5.03 \mathrm{~g}$ & & \\
\hline
\end{tabular}

Figures with different small letters are statistically different $(\mathrm{p}<0.05)$

Table 8 Flavor of Apricot nectar stored at room temperature

\begin{tabular}{|c|c|c|c|c|c|c|c|c|c|}
\hline \multirow{3}{*}{ Treatments } & \multicolumn{7}{|c|}{ Storage Interval (Days) } & \multirow[b]{2}{*}{ Means } & \multirow{2}{*}{$\begin{array}{c}\% \\
\text { Decrease }\end{array}$} \\
\hline & $\begin{array}{c}\text { Initial } \\
\text { Reading }\end{array}$ & 15 & 30 & 45 & 60 & 75 & 90 & & \\
\hline & \multicolumn{9}{|c|}{ Score rate for Flavor } \\
\hline $\mathrm{T}_{0}$ & 7.9 & 7.3 & 6.8 & 5.9 & 4.6 & 3.8 & 3.1 & $5.62 \mathrm{e}$ & 53.16 \\
\hline $\mathrm{T}_{1}$ & 7.9 & 7.2 & 6.7 & 6.1 & 5.8 & 5.3 & 5.1 & $6.3 \mathrm{~d}$ & 35.44 \\
\hline $\mathrm{T}_{2}$ & 7.8 & 7.4 & 7 & 6.5 & 6.1 & 5.7 & 5.3 & $6.57 \mathrm{ab}$ & 33.75 \\
\hline $\mathrm{T}_{3}$ & 8 & 7.1 & 6.8 & 6.3 & 6 & 5.8 & 5.5 & $6.5 \mathrm{bc}$ & 31.25 \\
\hline $\mathrm{T}_{4}$ & 7.9 & 7.5 & 7.1 & 6.6 & 5.9 & 5.5 & 5.1 & $6.52 \mathrm{bc}$ & 36.25 \\
\hline $\mathrm{T}_{5}$ & 7.9 & 7.2 & 6.9 & 6.3 & 6 & 5.7 & 5.2 & $6.45 c$ & 34.17 \\
\hline $\mathrm{T}_{6}$ & 8 & 7.5 & 7 & 6.6 & 6.2 & 5.9 & 5.4 & $6.65 a$ & 32.5 \\
\hline $\mathrm{T}_{7}$ & 7.8 & 7.3 & 6.8 & 6.4 & 6.1 & 5.9 & 5.6 & $6.58 \mathrm{ab}$ & 30 \\
\hline Mean & $7.96 a$ & $7.31 \mathrm{~b}$ & $6.88 \mathrm{c}$ & $6.33 \mathrm{~d}$ & $5.83 \mathrm{e}$ & $5.45 \mathrm{f}$ & $5.03 \mathrm{~g}$ & & \\
\hline
\end{tabular}

Figures with different small letters are statistically different $(\mathrm{p}<0.05)$

\section{Overall acceptability}

The overall acceptability of the samples of apricot treated with chemicals preservatives was initially ( $\mathrm{T}_{0}$ to $\mathrm{T}_{7}$ ) having values 8.0, 8.0, 8, 1, 8.1,7.9, 7.9, 8.1 and 7.8 which were slowly drop to $3.2,5.1,55,5.4,5.6,5.3,6.0$ 
and 5.7 during storage at ambient temperature for 90 days (Table 9). The (mean value) overall acceptability significantly $(\mathrm{p}<0.05)$ lower down from 7.01 to 5.58 during examination of research. During research highest value for mean were evaluated in sample $\mathrm{T}_{6}(7.01)$ followed by $\mathrm{T}_{7}$ (6.8), whereas decrease value for mean was noted in $\mathrm{T}_{0}$ (5.58) followed by $\mathrm{T}_{1}$ (6.34). During storage highest decline was pointed out in $\mathrm{T}_{0}(60.0 \%)$ followed by $\mathrm{T}_{1}(36.25 \%)$ while smallest decline was noted in $\mathrm{T}_{6}(25$. $0 \%$ ) followed by $\mathrm{T}_{5}(27.16 \%)$. Din et al [24] also reported a decrease in overall acceptability of beverages prepared from different ratios of bitter gourd during storage.

Table 9. Over all acceptability of Apricot nectar stored at room temperature

\begin{tabular}{|c|c|c|c|c|c|c|c|c|c|}
\hline \multirow{3}{*}{ Treatments } & \multicolumn{7}{|c|}{ Storage Interval (Days) } & \multirow[b]{2}{*}{ Means } & \multirow[b]{2}{*}{$\%$ Decrease } \\
\hline & $\begin{array}{c}\text { Initial } \\
\text { Reading }\end{array}$ & 15 & 30 & 45 & 60 & 75 & 90 & & \\
\hline & \multicolumn{9}{|c|}{ Score rate for overall acceptability } \\
\hline $\mathrm{T}_{0}$ & 8 & 7.3 & 6.5 & 5.7 & 4.6 & 3.8 & 3.2 & $5.58 \mathrm{f}$ & 60 \\
\hline $\mathrm{T}_{1}$ & 8 & 7.3 & 6.6 & 6.1 & 5.8 & 5.5 & 5.1 & $6.34 \mathrm{e}$ & 36.25 \\
\hline $\mathrm{T}_{2}$ & 8.1 & 7.5 & 7.1 & 6.7 & 6.2 & 5.9 & 5.5 & $6.71 b c$ & 32.09 \\
\hline $\mathrm{T}_{3}$ & 8.1 & 7.7 & 7.3 & 6.8 & 6.1 & 5.8 & 5.4 & $6.74 b c$ & 33.33 \\
\hline $\mathrm{T}_{4}$ & 7.9 & 7.3 & 7 & 6.6 & 6.3 & 6 & 5.6 & $6.68 c$ & 30 \\
\hline $\mathrm{T}_{5}$ & 7.9 & 7.5 & 6.9 & 6.3 & 6 & 5.8 & 5.3 & $6.55 \mathrm{~d}$ & 27.16 \\
\hline $\mathrm{T}_{6}$ & 8.1 & 7.7 & 7.3 & 7 & 6.7 & 6.3 & 6 & $7.01 \mathrm{a}$ & 25 \\
\hline $\mathrm{T}_{7}$ & 7.8 & 7.6 & 7.2 & 6.8 & 6.3 & 6 & 5.7 & $6.8 b$ & 28.75 \\
\hline Mean & $8.05 \mathrm{a}$ & $7.48 b$ & $6.98 \mathrm{c}$ & $6.5 \mathrm{~d}$ & $6 e$ & $5.63 \mathrm{f}$ & $5.22 \mathrm{~g}$ & & \\
\hline
\end{tabular}

Figures with different small letters are statistically different $(\mathrm{p}<0.05)$

\section{Conclusion and recommendations}

In this research preservatives named potassium Metabisulphite, sodium benzoate and potassium sorbate were used for sensory analysis of apricot nectar stored at room temperature. It was concluded from this research that sodium benzoate and potassium sorbate should be used in apricot nectar for longer storage because these two preservatives significantly help in maintaining quality attributes. Both sodium benzoate and potassium sorbate were identified as suitable preservatives to retain the quality and extend the shelf life of apricot nectar unto 90 days. The apricot nectar of $\mathrm{T}_{6}$ $=$ (Apricot nectar +sodium benzoate +potassium sorbate $0.1 \%$ ) gives best results followed by $\mathrm{T}_{2}=$ (Apricot nectar + Sodium benzoate $0.1 \%$ ) on the basis of physico chemical and sensory analysis.

\section{Authors' contributions}

Conceived and designed the experiments: A Khan \& Z Rahman, Performed the experiments: A Khan \& AU Rehman, Analyzed the data: A Ali, Contributed reagents/ materials/ analysis tools: ZU Rehman \& H Waqas, Wrote the paper: A Khan, Shah Saoud \& K Akbar.

\section{References}

1. Khattak, JZK, Hussain A, Ahmad B, FazalUl-Rehman M, Ullah Z, Arshad H \& Hussain A (2014). Microbiological stability of chemically preserved apricot 
nectar. Advancements in Life Sciences 1(3): 153-159.

2. Chevallier A (1996). The encyclopedia of medicinal plants. New York \& DK Publishing.

3. Egea MI, Martinez MC, Sanchez-Bel P, Muricia MA \& Romojaro F (2007). The influence of electronbeam ionization on ethylene metabolism and quality parameter in apricot (Prunus armeniaca L.,). Swiss Soc Food Sci Technol 40: 1027-1035.

4. Y1ldı, F (1994). New technologies in apricot processing. J. of Standard, Apricot Special Issue, Ankara, pp. 67-69.

5. Akpan UG \& Kovo AS (2005). Leonardo J Sci 7: 17-22.

6. Larmond E (1977). Lab methods of sensory evaluation of food. Pub. Canada, Deptt Agri Ottawa.

7. AOAC (2012). Official methods of analysis Association of Official and Analytical chemists $17^{\text {th }}$ Edi. Washington, DC.

8. Steel RGD \& Torrie JH (1998). Principles and procedures of statistics. Mc. Graw Hill Pub. Co. Inc. New York.

9. Lindort S (1980). Thermal distraction of park line in berries and berry jam. $J$ of Food Safety 2: 165-170.

10. Ehsan EB, Naeem ZP, Ghafoor A \& Bahtti MS (2002). Pak J of Food Sci 13: 11-15.

11. Ehsan EB, Naeem ZP, Javed A \& Nazir A (2003). Development, standardization and storage studies on grape fruit apple marmalade. Pak J of Food Science 13: 1115.

12. Shakir I, Durrani Y, Hussain I, Qazi MI \& Zeb I (2008). Physiochemical analysis of apple and pear mixed fruit jam prepared from varieties grown in azad $\mathrm{J}$ and K. Pak $J$ of Nutrition 7: 177-180.

13. Germain P \& Linden G (1981). Activités enzymatiques. In: Analyse des constituants alimentaires. (Eds.): B. Deymier,

14. Favier JC, Ireland RJ, Laussuc C \& Feinberg M (1993). Répertoiregénéral des aliments.
Tome 3: Table decomposition des fruits exotiques, fruits de cueilletted' Afrique. INRA (Ed.), pp. 55-59.

15. Abbasi NA, Zafar I, Maqbool M \& Hafiz IA (2009). Post-harvest quality of mango (Mangifera indical.) fruit as affected bychitosan coating. Pak J Bot 41(1): 343357.

16. Zeb, A, Ahmad I \& Ayub M (2009). Grape juice preservation with benzoate and sorbate. J Advance in Food Sci 31(1): 17-21.

17. Ayub M, Durrani T, Zeb A \& Ullah. J (2007). Effect of Sucrose and Potassium Metabisulphite on the Physicochemical and Microbial Analysis of Apricot Nectar. PakJ Sci Ind Res 50(4) 251-253.

18. Islam NIU (1986). Some physic chemical studies on the mango nectar stored in glass bottles. MSc, Thesis Deptt of food. tech., Uni of Agri. Faisalabad pp. 49.1986.

19. Iqbal M (1993). Effect of some chemical preservatives on the quality of mango nectar during storage, MSc thesis, Deptt of food tech, Uni of agriculture Faisalabad 57.

20. Babsky T, Toribio JL \& Lozano JE. (1986). Influence of storages on the composition of clarified apple juice concentrate. J Food Sci 51(3): 564-567.

21. Pruithi, JS, Marian JK \& Teotia MS (1984). Studied on the utilization of the kinnow and malta orange. J Food Sci Tech 21(3): 123127.

22. Gonzalez, ER \& Leeson S (2000). An investigation on the preservation of kununzaki, an African fermented cereal based food

23. Wills RBH, Mcglasson WB, Graham D, Lee TH \& Hall EG (1989). An Introduction to the Physiology and Handling of Fruit and Vegetables. Oxford, London, Edinburgh, Boston, Melbourne. BSP Professional Books.

24. Din A, Bukhari SAH, Salam A \& Ishfaq B (2011). Development of functional and dietetic beverage from bitter gourd. Internet $J$ of Food Safety 13: 355-360. 